\title{
INOVASI RANCANGAN PRODUK DAN BISNIS MODEL TERMOPLASTIK DARI TEPUNG SINGKONG
}

\author{
Elfira Febriani \\ Teknik Industri, Fakultas Teknologi Industri, Universitas Trisakti \\ e-mail: elfira.febriani@trisakti.ac.id
}

\begin{abstract}
ABSTRAK
Pengembangan plastik biodegradable dari tepung singkong sangat potensial untuk dikembangkan karena bahan baku yang mudah didapatkan terutama di Indonesia. Plastik yang menggunakan bahan baku tepung singkong merupakan sebuah invensi yang harus dikembangkan untuk mengurangi masalah pencemaran lingkungan sehingga dapat menjadi sebuah bisnis yang dapat berkembang. Oleh sebab itu tujuan dari makalah ini adalah mengusulkan rancangan produk dan bisnis model termoplastik dari tepung singkong. Dalam perancangan produk untuk menghasilkan termoplastik menggunakan beberapa jenis bahan utama yaitu tepung tapioka, magnesium stearat, serta bahan pemlastis berupa gliserol 99\% $(b / b)$ serta akuades maka jika dihubungkan dengan teori tepung singkong berpotensi untuk dijadikan termoplastik dikarenakan memiliki kandungan pati (80-90\%) dan serat (1.5-3\%) yang tergolong cukup tinggi. Pada awalnya target pasar mungkin lebih ditujukan kepada masyarakat yang memiliki konsep back to nature. Rancangan termoplastik tersebut jika dirancang dalam sebuah model bisnis dengan konsep Business Model Canvass (BMC) yang terdiri dari sembilan elemen. Sembilan elemen BMC terdiri atas customer segments, value prepositions, channels, customer relationship, revenue streams, key resources, key activities, key partnership dan cost structure.
\end{abstract}

Kata kunci: Rancangan Produk, Termoplastik, Business Model Canvass

\begin{abstract}
Biodegradable plastic from cassava flour is very potential to be developed because the raw materials are easily available in Indonesia. Plastic by using cassava flour is an invention that must be developed to reduce the environmental pollution issue so it can be a potential business. Therefore the aim of this paper is propose for product design and business model of thermoplastic from cassava flour. In the design of products to produce thermoplastics are using several main types of ingredients ie tapioca starch, magnesium stearate, and 99\% glycerol $(w / b)$ and aquades then if related to the theory of cassava flour to remain thermoplastic having starch content (80-90\% and fiber (1.5-3\%) which is quite high. On the target market target may be more addressed to people who have the concept of back to nature. Thermoplastic business model is designed by Business Model Canvas (BMC) that consisting of nine elements. The nine elements of BMC consist of customer segments, value propositions, channels, customer relationships, revenue streams, key resources, key activities, key partnerships and cost structures.
\end{abstract}

Keywords: Product Design, Thermoplastic, Business Model Canvass

\section{PENDAHULUAN}

Saat ini persediaan minyak bumi terbatas dan kebanyakan plastik sintetik tidak dapat didegradasi oleh lingkungan. Industri makanan memainkan peranan penting dalam penggunaan plastik untuk perlindungan sebelum, selama, dan setelah panen untuk menjamin keadaan bahan atau produk [1]. Misalnya produk konsumen yang umum digunakan seperti piring, gelas, sendok, pisau, film atau lapisan film dan tas [2].

Plastik dihasilkan dari sumber fosil telah memberikan kontribusi yang signifikan terhadap peningkatan pencemaran lingkungan yang disebabkan oleh akumulasi sampah yang tidak bisa didegradasi di tempat pembuangan sampah, sehingga mendorong pencarian bahan biodegradable baru tidak hanya dalam makanan, tetapi juga di medis, otomotif, dan sebagainya. Bahan baku alami terbarukan menjadi alternatif penting, termasuk tepung, pati, serat alami, protein, dan bahan lainnya yang dapat digunakan untuk mengembangkan bioplastik [3].

Saat ini plastik yang dapat didegradasi menjadi perhatian utama bagi masyarakat dunia. Banyak industri yang mulai menggunakan plastik biodegradable untuk 
melindungi produk mereka. Plastik biodegradable menggunakan bahan baku dan produk sampingan pertanian, seperti dari jagung dan singkong dan umbi kentang.

Pengembangan plastik biodegradable dari tepung singkong potensial untuk dikembangkan karena bahan baku yang mudah didapatkan terutama di Indonesia. Plastik yang menggunakan bahan baku tepung singkong merupakan sebuah invensi yang harus dikembangkan untuk mengurangi masalah pencemaran lingkungan sehingga akan dapat menjadi sebuah bisnis yang terus dapat berkembang.

Setiap kali sebuah bisnis yang didirikan, baik secara eksplisit maupun implisit menggunakan model bisnis tertentu yang menggambarkan arsitektur penciptaan nilai, pengiriman, dan mekanisme pengambilan keputusan dilakukan oleh perusahaan bisnis tersebut. Inti dari model bisnis adalah bahwa perusahaan mendefinisikan cara bagaimana perusahaan memberikan nilai kepada pelanggan, pelanggan membayar nilai, dan mengubah pembayaran tersebut untuk keuntungan sehingga mencerminkan hipotesis manajemen mengenai apa yang pelanggan inginkan, bagaimana mereka menginginkannya, dan bagaimana suatu perusahaan dapat mengatur terbaik untuk memenuhi kebutuhan tersebut, dibayar untuk melakukannya, dan membuat keuntungan.

Model bisnis sangat diperlukan untuk pengembangan invensi plastik biodegradable dari tepung singkong untuk mengurangi permasalahan lingkungan. Model bisnis yang disarankan menggunakan Business Model Canvass (BMC) diharapkan dapat berjalan dengan baik sehingga dapat memberikan keuntungan. BMC adalah sebuah model bisnis yang menggambarkan dasar pemikiran tentang bagaimana sebuah organisasi atau perusahaan menciptakan, menyerahkan, dan menangkap suatu nilai [4]. Dewasa ini tidak ada kepastian mengenai konsep model bisnis. Maka dari itu konsep BMC merupakan konsep yang dapat menjadi bahasa bersama yang memungkinkan untuk menggambarkan dan memanipulasi model bisnis untuk membuat alternatif kebijkan strategi yang baru.
Adanya permasalahan yang telah dijelaskan sebelumnya maka tujuan dari penulisan makalah ini adalah mengusulkan ide baru yaitu rancangan produk termoplastik dari tepung singkong sehingga produk tersebut dapat dikomesialkan serta model bisnis yang dapat digunakan untuk pengembangan produk termoplastik dari tepung singkong.

\section{METODOLOGI PENELITIAN}

\section{Identifikasi Kandungan Tepung Singkong}

Kandungan tepung singkong telah banyak diberikan oleh beberapa literatur. Setiap singkong memiliki kandungan pati yang berbeda-beda. Oleh sebab itu pada mengacu kepada Charles, Sriroth, dan Huang [5] diambil rata-rata atau interval kandungan tepung singkong.

\section{Rancangan Produk Termoplastik}

Untuk rancangan produk termoplastik dilakukan dalam skala laboratorium terlebih dahulu untuk mengetahui bahan dasar tepung singkong dapat menjadi termoplastik. Bahan utama yang digunakan yaitu tepung tapioka, magnesium stearat, serta bahan pemlastis berupa gliserol 99\% (b/b) serta akuades. Pencampuran bahan kering didahului oleh penambahan sejumlah tapioka ke dalam sebuah wadah. Kemudian secara perlahan ditambahkan magnesium stearat sebanyak 2\% (b/b) ke dalam wadah tersebut. Sementara itu, pada wadah lain dilakukan pencampuran antara gliserol dengan akuades. Akuades yang ditambah diatur sehingga kadar air mencapai $\pm 25 \%$. Selanjutnya campuran secara perlahan ditambahkan ke dalam wadah berisi larutan gliserol dan diaduk hingga tercampur merata. Proses pengadukan dalam wadah dilakukan secara kontinyu selama 5 menit. Kemudian campuran disimpan/diperam pada wadah plastik tertutup minimal selama 1 hari pada suhu ruang untuk penyempurnaan penyerapan bahan.

\section{Rancangan Model Bisnis}

Dalam makalah ini akan dibuat rancangan model bisnis berdasarkan dari Business Model Canvas (BMC) dari Osterwalder dan Pigneur [4]. Sembilan elemen BMC terdiri atas customer segments, value prepositions, 


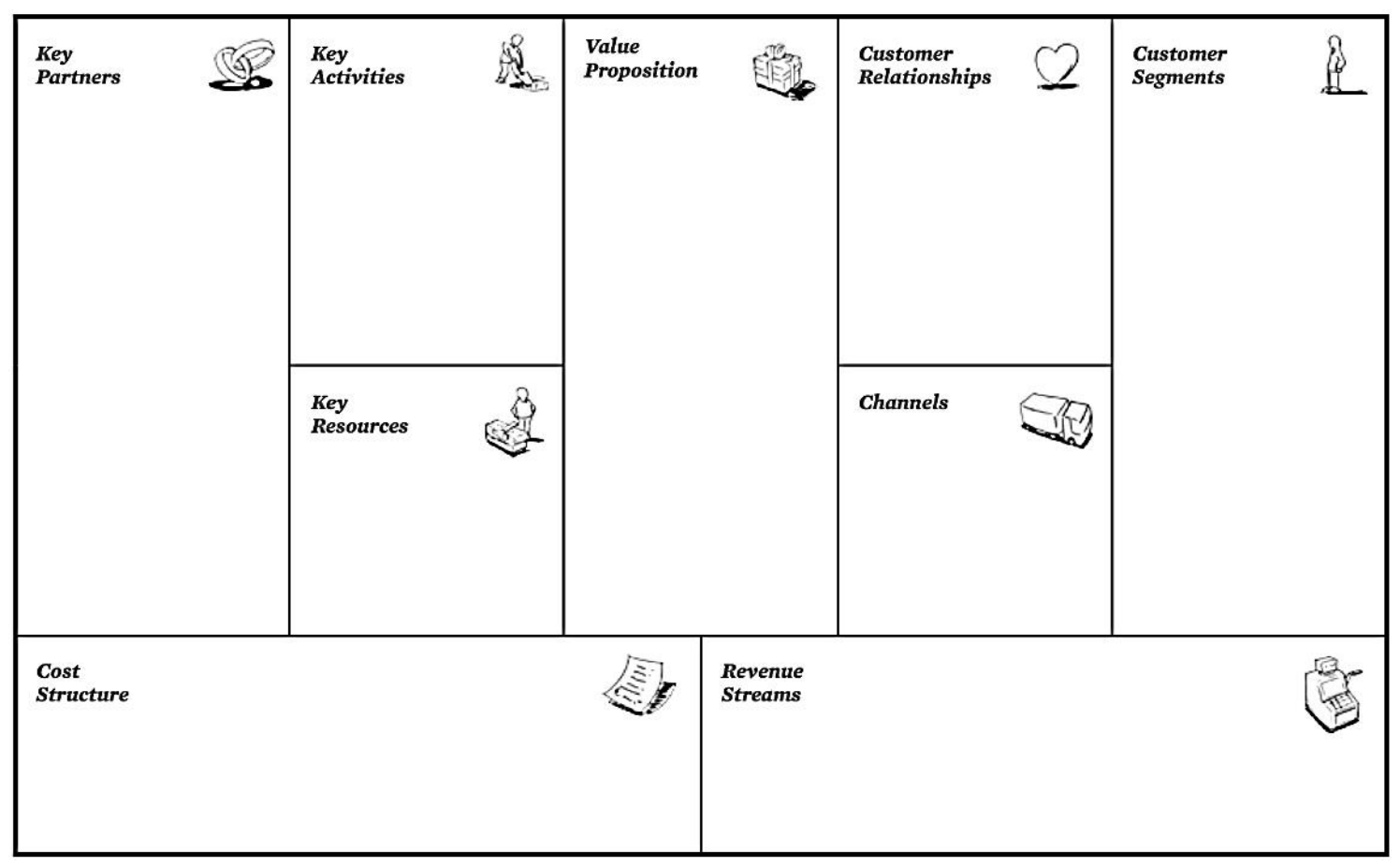

Gambar 1. Business Model Canvass (BMC) [4]

channels, customer relationship, revenue streams, key resources, key activities, key partnership dan cost structure. Adapun struktur dari BMC dapat dilihat pada Gambar 1 [4].

\section{HASIL DAN PEMBAHASAN}

\section{Deskripsi Ide}

Termoplastik adalah polimer yang mempunyai sifat tidak tahan terhadap panas. Jika polimer jenis ini dipanaskan, maka akan menjadi lunak dan didinginkan akan mengeras. Proses tersebut dapat terjadi berulang kali, sehingga dapat dibentuk ulang dalam berbagai bentuk melalui cetakan yang berbeda untuk mendapatkan produk polimer yang baru. Polimer yang termasuk polimer termoplastik adalah jenis polimer plastik. Jenis plastik ini tidak memiliki ikatan silang antar rantai polimernya, melainkan dengan struktur molekul linear atau bercabang. Bentuk struktur termoplastik dapat dilihat pada Gambar 2. berikut.

Contoh plastik termoplastik sebagai

Polietilena $(\mathbf{P E})=$ Botol plastik, mainan, bahan cetakan, ember, drum, pipa saluran, isolasi kawat dan kabel, kantong plastik dan jas hujan.

Polivinilklorida $($ PVC) = pipa air, pipa plastik, pipa kabel listrik, kulit sintetis, ubin plastik, piringan hitam, bungkus makanan, sol sepatu, sarung tangan dan botol detergen.

Polipropena (PP) = karung, tali, botol minuman, serat, bak air, insulator, kursi plastik, alat-alat rumah sakit, komponen mesin cuci, pembungkus tekstil, dan permadani.

Polistirena = Insulator, sol sepatu, penggaris, gantungan baju.
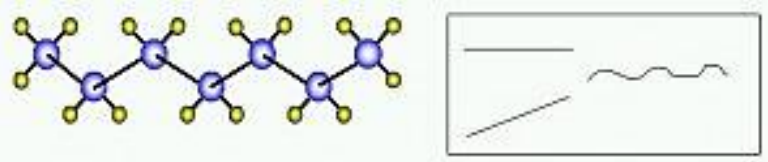

Gambar 2. Struktur termoplastik

Thermoplastik sintesis yang digunakan selama ini tidak dapat didaur ulang sehingga menimbulkan pencemaran lingkungan. Oleh karena itu tepung singkong dapat menjadi bahan termoplastik melalui pemcahan rantai molekul dalam kondisi suhu tertentu [6] sehingga TCF (Thermoplastic Cassava Flour) dapat menjadi salah satu bahan penting dalam pengembangan plastik biodegradable. Namun penggunaan TCF tersebut dalam pengembangan bahan biodegradable harus dibatasi karena masalah yang terkait dengan kelangsungan hidup masyarakat. Penggunaan bahan pangan untuk produk non pangan dapat mengakibatkan 
kompetisi untuk mendapatkan bahan tersebut. Untuk itu, salah satu strategi untuk meminimalkan masalah ini diantaranya adalah modifikasi kimia tepung (silang dan esterifikasi) dan campuran TCF dengan polimer lain dan poliester biodegradable.

Tepung singkong terutama terdiri dari pati (80-90\%) dan serat (1,5-3\%) tergantung pada singkong yang diperoleh [5]. Hal ini dianggap sebagai bahan baku potensial di bidang pengembangan material baru, termasuk biokomposit, karena konsentrasi tinggi dari pati [7]. Tepung singkong harus memiliki kadar air tidak lebih dari 13\% untuk penyimpanan. Oleh sebab itu tepung singkong dapat digunakan sebagai bahan termoplastik.

Untuk memperoleh sifat plastis, tepung yang digunakan membutuhkan intervensi bahan tambahan dari luar yang biasa disebut bahan pemlastis. Selain itu bahan pemlastis tersebut juga berperan dalam meningkatkan laju alir campuran dalam mesin sekaligus menurunkan titik leleh campuran [8]. Bahan pemlastis yang umum digunakan adalah bahan-bahan yang mengandung sejumlah besar gugus $-\mathrm{OH}$ seperti sorbitol, glikol, xilitol, gliserol, dan beberapa senyawa gula [9].

Penggunaan gliserol sebagai pemlastis dalam produk pati termoplastik berfungsi sebagai perenggang antar molekul dan menurunkan tingkat interaksinya satu sama lain [10]. Penggunaan gliserol sebagai pemlastis telah dilakukan sebelumnya di mana gliserol dicampurkan pada komposit pati termoplastik pati sagu dan PE (polietilen). Penggunaan tersebut terlihat memiliki pengaruh bagi pati termoplastik yang dihasilkan dalam hal sifat mekanisnya. Selain itu, gliserol juga digunakan dalam pembuatan pati termoplastik untuk dijadikan busa (foam) [11].

Termoplastik dari tepung ini memiliki beeberapa keunggulan sekaligus kelemahan. Keunggulannya terletak pada sifatnya yang lebih mudah didegradasi oleh lingkungan mengakibatkan aplikasinya sebaiknya bahan yang siap buang atau yang tidak digunakan dalam waktu lama. Contoh dari hal tersebut adalah penggunaannya sebagai tee (dudukan bola pada olahraga golf) atau pot tanam untuk bibit tanaman perkebunan menggantikan polybag. Kedua contoh tersebut hanya membutuhkan sifat mudah dibentuk serta tidak membutuhkan sifat fisik yang terlalu baik atau daya tahan (durability) yang tinggi. Namun demikian meski lebih ramah lingkungan, campuran plastik yang dihasilkan juga akan memiliki kekurangan. Kekurangan tersebut terletak pada semakin rendahnya kekuatan tarik dan kekerasan dari plastik yang dihasilkan. Hal tersebut merupakan konsekensi dari penggunaan termoplastik yang memiliki sifat fisik yang lebih rendah sebagai komponen pencampurnya.

Penggunaan bahan termoplastik di Indonesia cukup tinggi. Sehingga industri yang memproduksi jenis termoplastik terutama termoplastik biodegradable cukup potensial jika dikembangkan. Dengan konsep back to nature termoplastik biodegradable dan keunggulan yang dimiliki maka termoplastik ini mempunyai peluang pasar yang cukup untuk dikembangkan. Misalnya produk yang akan dikeluarkan adalah pot tanaman pengganti polybag yang dapat langsung di tanam di tanah tanpa harus melepas plastiknya terlebih dahulu. Target konsumen untuk produk ini adalah para petani, pecinta tanaman, pengusaha tanaman dan sebagainya.

\section{Rancangan Produk}

Suatu invensi yang baru dikenalkan dan akan dikomersialisasi maka akan banyak sekali pengembangan baik proses maupun teknologi yang perlu dikembangkan kembali. Munculnya ide kemudian ketika mulai dikembangkan dalam skala kecil akan berbeda dan akan terjadi banyak masalah ketika ingin diaplikasikan ke dalam skala industri. Oleh sebab itu saat mulai melakukan rancangan produk harus disesuaikan atau dipertimbangkan baik teknologi maupun proses untuk skala industri.

Ketika produk yang telah dihasilkan masuk ke dalam pasar, harga yang ditawarkan akan sedikit lebih mahal dibandingkan dengan kantong plastik sintetis. Pada awalnya target pasar mungkin lebih ditujukan kepada masyarakat yang memiliki konsep back to nature atau industri atau perusahaan yang lebih menyukai produk kemasan biodegradable. Harga produk ini dapat terus mengalami 
penurunan jika terus dilakukan pengembangan teknologi maupun proses sehingga harga jual dan harga produksi lebih murah.

Rancangan produk saat ini masih berupa skala lab yaitu dengan menggunakan bahan dan alat yang sederhana sehingga menghasilkan sebuah termoplastik. Rancangan produk tersebut perlu dilakukan uji fisik (kekuatan tarik, lama waktu terurai dan sebagainya). Selain itu perlu juga dilakukan analisis jika dilakukan scale up sampai pada tahap industri, analisis biaya, dan sebagainya. Namun hingga tahap laboratorium rancangan ini layak atau dapat dijadikan sebagai barang substitusi plastik yang telah beredar dipasaran saat ini.

\section{Model Bisnis}

Model bisni yang digunakan adalah Business Model Canvas. Pertama dari sisi Value Preposition yang terdiri dari beberapa elemen. Pada elemen newness yang artinya suatu value yang belum ada sebelumnya, termoplastik dari tepung singkong terbuat dari tepung singkong dengan memanfaatkan kandungan serat yang cukup tinggi. Jenis plastik biodegradable saat ini berasal dari hasil modifikasi asam laktat hasil perubahan zat tepung kentang atau jagung dan poliaspartat sintesis yang dapat terdegradasi.

Untuk elemen price belum dapat ditetapkan karena belum adanya perhitungan harga namun diprediksi akan lebih murah dibandingkan dengan plastik yang biodegradable yang ada. Kemudian pada elemen pengurangan resiko maka termoplastik dari tepung singkong merupakan salah satu alternatif dalam mengurangi resiko besarnya penumpukan sampah di Indonesia. Jika dilihat dari bahan yang digunakan maka termoplastik ini aman digunakan dan dapat terdegradasi oleh alam dengan baik.

Pada sisi customer relationship untuk produk ini salah satu tujuannya adalah customer aquisition yang artinya terus menerus mencari pelanggan baru. Selain itu tujuan lainnya adalah customer retention yaitu menjaga hubungan baik untuk pelanggan lama. Beberapa cara yang dapat dilakukan untuk mendapatkan pelanggan adalah dengan melakukan teknik pemasaran dari media online ataupun offline. Kemudian dengan adanya kerjasama dengan bank juga dapat membantu promosi dengan memberikan diskon kepada nasabah bank nya.

Pada sisi revenue stream yang merupakan arus pendapatan yang nantinya akan dihasilkan dari masing-masing segmen pelanggan. Arus pendapatan dapat dihasilkan dari pendapatan transaksi yang dihasilkan dari satu kali pembayaran. Pendapatan akan meningkat dengan dilakukannya periklanan baik dari media online maupun offline.

Pada sisi key resource, menurut Osterwalder [4] key resources dibagi menjadi empat macam yaitu physical, intellectual, human dan financial. Aspek fisik adalah sesuatu yang mendukung proses produksi seperti ruang produksi, bangunan, kendaraan dan bahkan alat kerja administrasi yang akan digunakan untuk membuat termoplastik dari tepung singkong. Untuk aset intelektual yang dimiliki merupakan hak paten merk dagang. Aspek human atau sumber daya manusia merupakan jumlah SDM yang akan terlibat dalam proses produksi dan pemasaran sedangkan aspek keuangan untuk membangun bisnis merupakan modal sumber utama. Tanpa dukungan modal bisnis tidak dapat berjalan lancar dan besar kecilnya modal sangat mempengaruhi bentuk bisnis yang dijalankan.

Berdasarkan teori dari Osterwalder [4] kategori key activities untuk termoplastik tepung singkong termasuk dalam production yang artinya aktivitas yang dilakukan berhubungan dengan membuat dan menyampaikan produk dengan kualitas yang baik. Aliran bisnis yang memungkinkan dimulai dari pembelian bahan baku, pengolahan bahan baku, pengemasan hingga pengiriman barang ke konsumen.

Pada sisi key partnership menerangkan bahwa motivasi kemitraan yang dapat diterapkan adalah optimization dan economy of scale dimana akan sangat sulit untuk beroperasi hanya dengan mengandalkan sumber daya sendiri. Kerjasama dapat dilakukan antara supplier sebagai mitra bisnis yang menyediakan bahan baku. Mitra lain yang dapat menjadi penunjang berjalannya bisnis adalah bank dimana motivasi kemitraan ini termasuk dalam acquisition of particular resources and 
activities yaitu kemitraan yang dimotivasi oleh kebutuhan untuk memperoleh akses ke pelanggan contohnya pihak bank dapat memberikan diskon jika menggunakan transaksi dengan debit card atau credit card dari bank tertentu.

Pada sisi cost stucture pada model bisnis termoplastik difokuskan pada cost driven yang artinya fokus pada biaya yang minimal agar konsumen mendapat harga yang rendah tetapi memiliki kualitas yang lebih baik dibandingkan plastik yang beredar saat ini dan value driven yang artinya tidak mementingkan berapapun biaya yang dikeluarkan yang terpenting adalah nilai kepuasan yang didapat konsumen.

Sisi terakhir pada BMC adalah customer segments yang termasuk dalam jenis segmented yaitu produk diarahkan untuk memenuhi kebutuhan dan permalasahan pelanggan yang mempunyai gaya hidup back to nature.

\section{KESIMPULAN}

Kesimpulan dari makalah ini adalah tepung singkong dapat digunakan sebagai bahan baku termoplastik dikarenakan memiliki kadar serat yang cukup tinggi (1,5-3\%) dan pati (8090\%). Termoplastik dari tepung singkong dapat mengurangi pencemaran lingkungan akibat termoplastik sintetis yang tidak dapat hancur dengan sendirinya.

Rancangan model bisnis menggunakan BMC yang terdiri dari sembilan elemen. Customer segment termasuk dalam jenis segmented, value preposition dilihat dari sisi newness dan price, channels secara langsung pada konsumen, customer relationship berdasarkan customer aquisition dan customer retention, revenue streams berdasarkan pendapatan penjualan produk, key resources dilihat dari aspek physical, intellectual, human dan financial, key activities berdasarkan aktivitas untuk memproduksi termoplastik, key partnership berdasarkan acquisition of particular resources and activities, dan terakhir untuk cost structure difokuskan pada cost driven.

\section{DAFTAR PUSTAKA}

[1]. Weber C., 2001, Biobased Packaging Materials for the Food Industry, ISBN, 87-90504-07-0, Rolighedsvej, Denmark.
[2]. Wang Y., Rakotonirainy M., Padua W., 2003, Thermal Behavior Of Zeína-Base Biodegradable Films. In: Starch/Stärke, Vol. 55, No.1, (August 2011); pp. 25-29, ISSN 1521-379X.

[3]. Tharanathan R., 2003, Biodegradable Films and Composite Coatings: Past, Present and Future, Food Science and Technology, Vol. 14, No.3, (August 2011), pp. 71-78, ISSN 0924-2244.

[4]. Osterwalder A., Pigneur Y., 2010, Business Model Generation: A Handbook for Visionaries, Game Changers and Challangers, John Wiley\&Sons, Inc, New Jersey.

[5]. Charles A., Sriroth K., Huang T, 2005, Proximate Composition, Mineral Contents, Hydrogen Cyanide and Phytic Acid of 5 Cassava Genotypes, Food Chemestry, Vol. 92, No.4, (September 2011), pp. 615-620, ISSSN 0308-8146.

[6]. Rahman M., Brazel C., 2004, The Plasticizer Market: An Assessment of Traditional Plasticizers and Research Trends to Meet New Challenges, Progress in polymer science, Vol. 29, No.12, pp. 1223-1248, ISSN 0079-6700.

[7]. Martínez A., Velasco-Santos C., deIcazaa M., Castaño V., 2007, DynamicalMechanical and Thermal Analysis of Polymeric Composites Reinforced with Keratin Biofibers from Chicken Feathers, Composites: Part B, Vol. 38. No. 3. (September 2011) pp. 405- 410, ISSN 1359-8368.

[8]. Plackett D., Vaquez A., 2004, Natural Polymer Sources, Di dalam: Caroline Bailie (ed), Green composites: Polymer composites and the environment, CRC Press, Boca Raton, Cambridge.

[9]. Yang JH., Yu JG., Ma XF., 2006, A Novel Plasticizer for The Preparation of Thermoplastic Starch, Chinese Chemical Letters 17: 133-136.

[10]. Janssen L., 2009, Influence of Process Conditionson The Physical Properties of TPS, Di dalam: Leon J dan Leszeck M (ed), Thermoplastic Starch: a Green Material for Various Industries, WilleyVch, Weinheim. 
[11]. Cha JY., Chung DS., Seib PA., Flores RA., Hanna MA., 2000, Physical Properties of Starch-Based Foams As Affected By Extrusion Temperature and Moisture Content, Industrial Crops and Products, 14: 23-30. 